DOI: https://doi.org/10.32839/2304-5809/2021-3-91-24

УДК 351.72

Смолінська С.Д. Львівський національний університет імені Івана Франка Овчиннікова Т.В. ВП «Львівська фрілія» Київський національний університет культури і мистецтв

\title{
ФІНАНСОВЕ ЗАБЕЗПЕЧЕННЯ РЕГІОНАЛЬНОГО РОЗВИТКУ НА СУЧАСНОМУ ЕТАПІ РОЗВИТКУ УКРАЇНИ
}

Анотація. В статті визначено суть та особливості фінансового забезпечення регіонального розвитку на сучасному етапі розвитку України. Розглянуто основні владні органи, наділені державою повноваженнями у сфері управління фінансовим забезпеченням регіонів як інституційні елементи досліджуваного механізму. Розглянуто питання децентралізації та бюджетної децентралізації у напрямі покращення управління фрінансовим забезпеченням на регіональному рівні. Підсумовано, що прогресивний розвиток територій залежить від злагодженої взаємодії елементів механізму управління фрінансовим забезпеченням на регіональному рівні, які органічно пов'язані між собою і в сукупності становлять систему, на основі якої реалізуються управлінські функції держави.

Ключові слова: фрінансове забезпечення, регіональний рівень, децентралізація, бюджетна політика.

Smolinska Sifiia Lviv National University named by Ivan Franko Ovchynnikova Tetiana Kyiv National University of Culture and Arts

\section{FINANCIAL SUPPORT OF REGIONAL DEVELOPMENT AT THE CURRENT STAGE OF UKRAINE'S DEVELOPMENT}

Summary. The article defines the essence and features of financial support of regional development at the present stage of development of Ukraine. The peculiarities of functioning of the mechanism of financial security management at the regional level are considered in the article. It is argued that the management of regional development in the context of its sufficient financial support should be carried out within the appropriate legal framework, which determines the relationship between the state and the regions in terms of financial management of the territories. The main authorities endowed with the state powers in the field of financial management of the regions as institutional elements of the studied mechanism are considered. The financial elements of the mechanism, which are the financial resources needed by the subjects of regional policy to implement the main tasks of socio-economic development of individual territories of the state. The scheme of the mechanism of financial support management at the regional level is given. The principles on the basis of which financial support is provided at the regional level are substantiated. The requirements of the financial security management mechanism at the regional level are explained. It is proved that the relationship, which is carried out within the framework of financial support at the regional level, is implemented using general and specific methods that take into account the peculiarities of the development of individual territories in the state and its individual characteristics. The purpose of financial support at the regional level and its tasks are revealed. The issues of decentralization and budget decentralization in the direction of improving financial management at the regional level are considered. It is concluded that the progressive development of territories depends on the coordinated interaction of the elements of the financial management mechanism at the regional level, which are organically interconnected and together constitute the system on the basis of which the management functions of the state are implemented.

Keywords: financial support, regional level, decentralization, budget policy.

$\Pi$ остановка проблеми. Фінансове забезпечення відіграє важливу роль у процесі розвитку регіонів i допомагає розв'язувати численні соціально-економічні завдання, покликані підвищувати життевий рівень населення i сприяти загальнонаціональному прогресу на рівні окремих територіальних одиниць. А якщо врахувати проголошений в останні роки курс держаної політики на розвиток самоврядування на місцевому рівні, то питання забезпечення територіальних громад необхідними ресурсами, зокрема, фрінансовими, які задовольняють потреби регіонів, стає дедалі актуальнішим. Тому достатне фінансове забезпечення та управління ним, яке здійснюється з боку державних органів влади, має реалізовуватися у рамках функціонування результативного організаційного механізму, вдосконалення якого повинно бути пріоритетом державного управління на шляху до створення і забезпечення сприятливих умов для ефрективного функціонування регіонів.

Через те організаційні методи управління, які в сукупності становлять собою організаційний механізм, покликані знаходити відповіді на питання найедективнішого перерозподілу dpiнансових ресурсів у напрямі покращення регіонального розвитку.

Аналіз останніх досліджень і публікацій. Питання механізмів державного управління фрінансовим забезпеченням на регіональному рівні є надзвичайно актуальним, проте мало вивченим і в контексті науки державного управління. Велика кількість науковців, таких як Бондарук T.Г. [1], Бугай С.M. [2], Вахович I.M. [3], Клітін- 
ський Ю.С. [4], Кравченко С.О. [5], Міщук О.В. [6], Чернюк Л.Г. [7] та інші дослідники розглядають особливості регіональної політики та фрінансового забезпеченню на регіональному рівні.

Виділення невирішених раніше частин загальної проблеми. Проте ці питання потребують значної уваги та ґрунтовних наукових досліджень в контексті ефрективного функкіонування механізму управління фінансовим забезпечення на регіональному рівні, що зумовлюе актуальність обраної теми статті.

Постановка завдання. Метою статті є дослідження особливостей фінансовим забезпечення на регіональному рівні та його основних атрибутів у контексті підвищення його ефективності та покращення здійснення управлінських дій у фінансовій сфері, які стосуються розподілу та перерозподілу фінансових ресурсів на регіональному рівні.

Виклад основного матеріалу дослідження. Як і кожна складна система, що складаеться 3 комплексу взаємопов'язаних елементів, механізм управління фінансовим забезпеченням на регіональному рівні повинен функціонувати на основі конкретно визначених принципів, реалізовуватися 3 чіткою метою його здійснення, вирішувати поставлені перед ним завдання і вимоги, та виконувати функції за допомогою певних методів.

Управління регіональним розвитком у контексті його достатнього фрінансового забезпечення повинно здійснюватися в рамках належної законодавчо-правової бази, яка визначае взаємовідносини держави та регіонів в плані управління фінансовим забезпеченням територій. Зокрема, мова йде про закони про Державний бюджет України, про державні та регіональні програми економічного і соціального розвитку територій та про інші нормативні документи, на основі яких регулюються процеси управління фінансовим забезпеченням на регіональному рівні та здійснюеться правове регулювання діяльності господарюючих суб’ектів. Окремо варто згадати Закон України «Про симулювання розвитку регіонів», в якому визначено, що «фінансування стимулювання розвитку регіонів та подолання депресивності територій здійснюеться за рахунок коштів, передбачених на цю мету в законах України про Державний бюджет України та рішеннях про місцеві бюджети ... на відповідні роки, та інших джерел відповідно до законодавства» [8].

Стосовно інституційних елементів досліджуваного механізму, то тут слід згадати основні владні органи, наділені державою повноваженнями у сфері управління фінансовим забезпеченням регіонів:

- Кабінет Міністрів України як основний центральний орган виконавчої влади, який забезпечуе виконання стратегічних завдань державного управління регіональним розвитком щодо територіального забезпечення фінансовими ресурсами;

- інші центральні органи влади, відповідальні за реалізацію фінансової політики на регіональному рівні;

- місцеві органи виконавчої влади та органи місцевого самоврядування, які виконують покладені на них державою повноваження стосовно фінансового забезпечення підконтрольних їм територій.
Всі ці органи влади взаємодіють між собою шляхом укладання угод регіонального розвитку, в яких визначаються основні положення щодо фінансового забезпечення відповідних територій в рамках державної та регіональної стратегій.

Що ж до фінансових елементів досліджуваного механізму, то тут слід згадати ті фінансові ресурси, які необхідні суб'ектам регіональної політики для реалізації основних завдань соціально-економічного розвитку окремих територій держави. Їх достатня кількість досягається шляхом проведення ефективної податкової, інвестиційної та бюджетної політики, яка повинна здійснюватися у напрямі прогресивного розвитку регіонів.

Зокрема, регіональна податкова політика відіграе особливу роль у забезпеченні збалансованості місцевих бюджетів, адже тут яскраво проявляється рівень зацікавленості держави щодо достатності територіального фінансового забезпечення шляхом регламентації кількості і обсягу необхідних до сплати в місцеві бюджети платежів. Тому ефективна податкова політика тісно взаємопов'язана з бюджетною політикою в плані достатнього наповнення місцевих бюджетів, що в подальшому сприяе сталому розвитку держави на субнаціональному рівні.

Слід зазначити, що в більшості розвинутих країн світу місцеві податки займають левову частку від усіх податкових надходжень до бюджетів різних рівнів. В Україні ж місцеве оподаткування не $є$ пріоритетним, тому в державі спостерігаеться значний дисбаланс бюджетних надходжень, що значним чином впливае на рівень фрінансового забезпечення на регіональному рівні.

У зв'язку з цим щораз більшої ваги набувае питання децентралізації, яке останнім часом стало надзвичайно актуальним, адже розподіл фрінансових ресурсів за принципом управління цим процесом на територіальному рівні дасть змогу набагато ефективніше використовувати кошти, яких потребуе окремий регіон. Це дає поштовх до соціально-економічних зрушень на рівні певних територій, розвитку реформ, підвищення загального рівня життя населення, а також сприяе залученню інвестицій, зокрема, з-за кордону.

Українська модель фінансової децентралізації $е$ ще незавершеною. Для порівняння із розвиненими країнами Європи інформацію представлено в табл. 1.

Варто зазначити, що основними завданнями регіональної фінансової політики є забезпечення економічної незалежності і розвитку регіону. Становлення та розвиток в Україні інституту місцевого самоврядування із самодостатніми місцевими бюджетами та передача місцевим органам влади визначених повноважень обумовлюють формування бюджетного процесу згідно із европейськими стандартами, що водночас передбачае пошук нових напрямів фінансового забезпечення регіонів [10, с. 163-164].

Бюджетна децентралізація передбачає здійснення заходів державного управління, які спрямовані на підвищення фінансової самостійності місцевих бюджетів. 3 цією метою законодавці внесли зміни до Податкового та Бюджетного кодексів та планують також внести зміни ще до рядку законодавчих актів та, зокрема, до Основного закону України у контексті розширення повноважень 


\section{Порівняльна характеристика моделей децентралізації в Україні та европейських країнах}

\begin{tabular}{|c|c|c|}
\hline Країна & $\begin{array}{c}\text { Адміністративно-територіальні } \\
\text { утворення }\end{array}$ & Фінансова децентралізація \\
\hline Україна & $\begin{array}{l}\text { Створено більше } 159 \text { об'єднаних } \\
\text { територіальних громад }\end{array}$ & $\begin{array}{l}\text { - розподіл податків між різними ланками бюджетної } \\
\text { системи; } \\
\text { - трансфертне фінансове вирівнювання (дотації, субвенції } \\
\text { та інші види міжбюджетних трансфертів) - вагоме місце } \\
\text { належить податку з доходів фрізичних осіб (понад } 20 \% \text { ), } \\
\text { місцеві податки складають більше } 14 \% \text { (надефективним } \\
\text { серед яких є податок на нерухомість) } \\
\text { - джерела наповнення місцевих бюджетів розширено за } \\
\text { рахунок переданих з державного бюджету низки податків } \\
\text { та запроваджено нові збори. }\end{array}$ \\
\hline Німеччина & $\begin{array}{l}\text { Територіальні одинищі: землі, } \\
\text { округи, райони та общини (базова } \\
\text { ланка) }\end{array}$ & $\begin{array}{l}\text { - розподіл податків між різними ланками бюджетної } \\
\text { системи; - трансфертне фінансове - громади наділені } \\
\text { правом самостійно встановлювати податкові ставки } \\
\text { та обирати джерела оподаткування. - Серед власних } \\
\text { податків - це промисловий, поземельний та споживчий, } \\
\text { а також закріплені - прибутковий та податок з } \\
\text { обороту. - Основним місцевим податком є промисловий. - } \\
\text { закріплення за кожним рівнем податків, які скеровуються } \\
\text { лише до одного з бюджетів }\end{array}$ \\
\hline Словаччина & $\begin{array}{l}\text { скасовано області і замість трьох } \\
\text { рівнів управління залишилось } \\
\text { два: райони (38) і територіальні } \\
\text { одиниці (121) }\end{array}$ & $\begin{array}{l}\text { - фрінансування власних функцій відбувається за рахунок } \\
\text { власних доходів громад; } \\
\text { - фінансування делегованих повноважень - за рахунок } \\
\text { цільових трансфертів. }\end{array}$ \\
\hline Польща & $\begin{array}{l}\text { - кількість повітів і гмін скорочено } \\
\text { до } 379 \text { та } 2479 \text { - кількість воєводств } \\
\text { скорочено з } 49 \text { до } 16 \text {; } \\
\text { - триступенева система } \\
\text { територіальних одиниць: «гміна - } \\
\text { повіт - воєводство» }\end{array}$ & $\begin{array}{l}\text { джерелами власних доходів бюджетів гміни стали: } \\
\text { податок на нерухомість, сільськогосподарський податок, } \\
\text { лісовий податок, податок з транспортних засобів, з доходів } \\
\text { фізичних осіб, податок на спадщину, а також низка } \\
\text { зборів: гербовий, місцевий, адміністративний та ін. Окрім } \\
\text { того, доходи форомуються надходженнями від податку } \\
\text { на доходи фізичних та юридичних осіб; цільовими } \\
\text { субвенціями, дотаціями }\end{array}$ \\
\hline
\end{tabular}

Джерело: [9]

місцевих органів влади щодо розширення їх повноважень у сфрері бюджетної політики.

Бюджетна децентралізація передбачає не стільки збільшення частки доходів місцевих бюджетів чи покращення фрінансування бюджетних установ на місцевому рівні, як покращення якісного фінансового забезпечення регіонального розвитку, спрямованого на підвищення життєвого рівня населення окремих територій. В іншому випадку спроба збільшення виділення коштів 3 державного бюджету на потреби окремих регіонів може призвести до бюджетної кризи на загальнодержавному рівні та неефективного використання державних коштів.

Таким чином, бюджетна децентралізація повинна передбачати: розширення повноважень місцевих органів влади стосовно можливості розпоряджання ними коштами, які надходять до місцевих бюджетів від сплати суб'єктами обов'язкових платежів; перегляд бюджетної трансфертної політики у напрямі зміни підходу щодо перерозподілу коштів зведеного бюджету з тим, щоб місцеві бюджети мали можливість забезпечувати підпорядковані їм території необхідними коштами для соціально-економічного розвитку визначеного регіону; зміна принципу оподаткування та перерозподілу надходжень від податкових платежів на користь місцевих бюджетів.

Проте незважаючи на цілі та завдання бюджетної децентралізації, які покликані підвищити якість фінансового забезпечення на регіональному рівні, на даний час спостерігається не стільки процес розширення повноважень місцевих органів влади, скільки процес збільшення централізації влади у протилежному напрямі. Слід відмітити, що здійснювана на сьогодні децентралізація має слабке місце у контексті наявності значної кількості трансфертів, які спостерігаються при перерозподілі коштів між державним та місцевим бюджетами. Така ситуація не є свідченням самостійності бюджетів, а створює додаткові проблеми для фрормування самостійності місцевих органів влади за умови проведення цивілізованих редорм у напрямі децентралізації.

Загалом, бюджетна політика як складова фрінансової політики держави відіграє важливу роль в економічних процесах країни та має проводитися відповідно до принципів едективності досягнення соціально-економічного розвитку країни. Шляхи застосування бюджетної політики залежать від економічних умов, в яких перебуває економічна система певної країни, та цілей, поставлених перед урядом, що приймає відповідні рішення [11].

Проте на даний час бюджетна система України перебуває на стадії вдосконалення взаємовідносин між учасниками бюджетних процесів. Недосконалість перерозподілу коштів державного та місцевого бюджетів спричиняе залежність окремих територій від центральних органів влади та їх політики. У свою чергу, це є свідченням недосконалої управлінської політики як на рівні держави, так і на рівні окремих територіальних 
одиниць. Також така ситуація свідчить і про слабкий соціально-економічний розвиток окремих регіонів країни.

Загалом, на наш погляд, здійснювана на сьогоднішній день децентралізація місцевих фрінансів та бюджетного процесу може розбалансувати всю бюджетну систему країни. Тому у цьому напрямі необхідно забезпечити чіткі нормативні приписи щодо регламентації бюджетної децентралізації, здійснюваної в державі. Зокрема, необхідно внести зміни до бюджету, до Бюджетного та до Податкового кодексу, а також прийняти два закони, які стосуються змін до земельних законів, та закони, які спрямовані на економічне посилення сільських, селищних громад. Також потрібно 3 метою підвищення бюджетної і фрінансової самостійності місцевих бюджетів закріпити за місцевими громадами достатній обсяг податку на доходи фрізичних осіб не нижче рівня минулих років.

Таким чином, прогресивний розвиток територій залежить від злагодженої взаємодії елементів досліджуваного механізму, які органічно пов'язані між собою і в сукупності становлять систему, на основі якої реалізуються управлінські фрункції держави. Це сприяе ефрективній реалізації моделі субнаціонального розвитку, на основі якої використовуеться фрінансовий потенціал регіонів і яка забезпечуе вагомий результат від використання фрінансових ресурсів місцевими органами влади.

Висновки. Механізм фрінансового забезпеченням на регіональному рівні виступає комплексним поняттям, що передбачає сукупність управлінських методів, інструментів, принципів та дій, здійснюваних з боку державних та місцевих органів влади щодо пошуку, залучення, розподілу та найбільш ефективного використання фрінансових ресурсів у напрямі збалансованого соціально-економічного розвитку певного регіону та покращення життя населення.

Як і кожна складна система, що складається 3 комплексу взаємопов'язаних елементів, фрінансове забезпечення на регіональному рівні повинен функціонувати на основі конкретно визначених принципів, реалізовуватися з чіткою метою його здійснення, вирішувати поставлені перед ним завдання і вимоги, та виконувати фрункції за допомогою певних методів. Особливий акцент в статті поставлено на процесах децентралізацї, яка в межах досліджуваного механізму повинна сприяти підвищенню ефективності фрінансового забезпечення регіонів.

\section{Список літератури:}

1. Бондарук Т.Г. Регулювання та фінансове забезпечення розвитку місцевого самоврядування : автореф. дис. ... д-ра екон. наук : спец. 08.00 .03 - економіка та управління національним господарством. Київ, 2010. 36 с.

2. Бугай С.М., Пухлій В.Т., Слівак А.Є. Проблеми становлення регіональної політики України та основні тенденції подальшого розвитку. Форлування ринкових відносин в Україні : зб. наук. праць / [наук. ред. І.Г. Манцуров]. Київ, 2009. Вип. 11(102). С. 163-169.

3. Вахович I.M. Теоретико-методологічні засади формування та реалізації регіональної політики фрінансового забезпечення сталого розвитку : автореф. дис. ... д-ра екон. наук : спец. 08.00.05 розвиток продуктивних сил і регіональна економіка. Одеса, 2008. 35 с.

4. Кравченко С.О., Марковський С.С. Сутність фрінансового забезпечення державної регіональної політики. Державне управління: теорія та практика. 2011. № 1. URL: http://www.academy.gov.ua/ej/ej13/txts/ Kravchenko.pdf (дата звернення: 22.03.2021).

5. Клітінський Ю.С. Формування фінансової політики на регіональному рівні. Науковий вісник: Фінанси, банки, інвестииї. 2013. № 3. С. 50-54.

6. Міщук О.В. Фінансове забезпечення економічного зростання: теоретичний аспект. Науковий вісник: Фінанси, банки, інвестииї̈. 2011. № 2. С. 9-12.

7. Чернюк Л.Г. Комплексність як невід'ємна умова ефективного розвитку регіональних господарських систем : Матеріали Міжнар. наук.-практ. конф. [«Регіональний розвиток України: проблеми та перспективи»], (Київ, 26 листоп. 2009 р.) / М-во освіти і науки України, ДВНЗ «Київ. нац. економ. ун.-т ім. В. Гетьмана», Рада по вивч. продукт. сил України НАН України [та ін.]. Київ : ДВНЗ «КНЕУ ім. В. Гетьмана», 2009. С. $720-723$.

8. Про стимулювання розвитку регіонів : Закон України від 8 вересня 2005 року № 2850 // Відомості Верховної Ради України. 2005. № 51. С. 2662-2668.

9. Демченко О.П., Яковенко К.А. Свропейський досвід бюджетної децентралізації та перспективи для України. Еконоліка і суспільство. 2018. Випуск 16. С. 724-730.

10. Бугай С.М., Пухлій В.Т., Слівак А.С. Проблеми становлення регіональної політики України. Київ, 2009. Вип. 11(102). С. 163-169.

11. Ситник Н.С., Ярема Б.П. Бюджетно-податкова політика України та напрями їі реалізації. Вісник Хлельницького національного університету. Львів : Економічні науки. 2016. № 2. Т. 1 (234). С. 75-80.

\section{References:}

1. Bondaruk T.G. (2010) Reguluvannya ta finansove zabezpechennya rozvytku mistsevogo samovryaduvannya [Regulation and financial support of local self-government development]. Extended abstract of doctor's thesis. Kyiv. (in Ukrainian)

2. Bugay S.M. (2009) Problemy stanovlennya regionalnoyi polityky Ukrainy ta osnovni tendentsiyi podalshogo rovytku [Problems of formation of regional policy of Ukraine and main trends of further development]. Formuvannya rynkovyh vidnosyn $v$ Ukraini. - Formation of market relations in Ukraine, 11(102), 163-169. (in Ukrainian)

3. Vahovych I.M. (2008) Teoretyko-metodologichni zasady formuvannya ta realizatsiyi regionalnoyi polityky finansovogo zabezpechennya stalogo rozvytku [Theoretical and methodological principles of formation and realization of the regional policy of financial support of sustainable development]. Extended abstract of doctor's thesis. Odesa. (in Ukrainian)

4. Kravchenko S.O. (2011) Sutnist finansovogo zabezpechennya derzavnoyi regionalnoyi polityky [Essence of financial support of the state regional policy]. Derzavne upravlinnya: teoriya ta practyka. - Public Administration: Theory and Practice, no. 1. Available at: http://www.academy.gov.ua/ej/ej13/ txts/Kravchenko.pdf (in Ukrainian) 
5. Klitinskyy U.S. (2013) Formuvannya finansovoyi polityky na regionalnomu rivni [Formation of financial policy at the regional level]. Finansy, banky, investytsiyi. - Finances, banks, investments, 3, 50-54. (in Ukrainian)

6. Mischuk O.V. (2011) Finansove zabezpechennya ekonomichnogo zrostannya: teoretuchnyy aspect [Financial support for economic growth: the theoretical aspect]. Finansy, banky, investytsiyi. - Finances, banks, investments, 2, 9-12. (in Ukrainian)

7. Chernyuk L.I. (2009) Kompleksnist yak nevidyemna umova efektyvnogo rozvytku regionalnyh gospodarskyh system [Complexity as an indispensable condition for the effective development of regional economic systems]. Kyiv, 720-723. (in Ukrainian)

8. Zakon Ukrainy "Pro stymulyuvannya rozvytku regioniv" (2005) [Law of Ukraine "On Stimulation of the Development of Regions"]. Vidomosti Verhovnoyi Rady Ukrainy. - Information from the Verkhouna Rada of Ukraine, 51, 2662-2668. (in Ukrainian)

9. Demchenko O.P. (2018) Europeyskyy dosvid budzetnoyi detsentralizatsiyi ta perspektyvy dlya Ukrainy [European experience of budgetary decentralization and prospects for Ukraine]. Ekonomika $i$ suspilstvo. - Economy and society, 16, 724-730. (in Ukrainian)

10. Bugay S.M. (2009). Problemy stanovlennya regionalnoyi polityky Ukrainy, 11(102), 163-169. (in Ukrainian)

11. Sytnyk N.S. (2016) Budzetno-podatkova polityka Ukrainy ta napryamy yiyi realizatsiyi [Fiscal policy of Ukraine and directions of its realization]. Visnyk Khmelnytskogo natsionalnogo universytetu. - Bulletin of the Khmelnytsky National University, 2(234), 75-80. (in Ukrainian) 